\title{
Pelaksanaan Pembelajaran Pendidikan Jasmani, Olahraga, dan Kesehatan
}

\author{
Revandi Imana Taqwim ${ }^{1}$, M. E Winarno ${ }^{1}$, Roesdiyanto ${ }^{1}$ \\ ${ }^{1}$ Pendidikan Olahraga-Universitas Negeri Malang
}

\section{INFO ARTIKEL}

\section{Riwayat Artikel:}

Diterima: 26-07-2019

Disetujui: $18-03-2020$

\section{Kata kunci: \\ implementation of learning; middle school student; \\ pelaksanaan pembelajaran; siswa SMP}

\author{
Alamat Korespondensi: \\ Revandi Imana Taqwim \\ Pendidikan Olahraga \\ Universitas Negeri Malang \\ Jalan Semarang 5 Malang \\ E-mail: revandiimanataqwim@yahoo.com
}

\begin{abstract}
ABSTRAK
Abstract: The purpose this of study is to take an overview of the implementation of the PJOK in SMP Kec. Pakis. The method used is descriptive analysis. With a total sample of 6 schools. data instrument using observation techniques. The results showed that the propulsion activities were still not in accordance with the standard with an average time of $10.64 \mathrm{~m}(9 \%)$, the core activities were still not in accordance with the standard with a time of $56.39 \mathrm{~m}(47 \%)$, closing activities were still lacking and not in accordance with time of $5.91 \mathrm{~m}(5 \%)$ and effectiveness activities are still far from the existing standard with $72.95 \mathrm{~m}(61 \%)$ with a fairly good category.

Abstrak: Tujuan penelitian ini yakni mengambil gambaran pelaksanaan pembelajaran PJOK SMP Kec. Pakis. Metode yang digunakan yaitu analisis diskriptif. Dengan jumlah sampel penelitian enam sekolah. Instrumen data dengan menggunakan teknik observasi. Hasil penelitian menunjukkan bahawa kegiatan pendahulan masih belum sesuai dengan standart dengan waktu rata-rata $10,64 \mathrm{~m}(9 \%)$, kegiatan inti juga masih belum sesuai dengan standart dengan waktu $56,39 \mathrm{~m}$ (47\%), kegiatan penutup masih kurang dan belum sesuai dengan waktu 5,91m (5\%) dan kegiatan efektivitas masih jauh dari standart yang ada dengan waktu $72,95 \mathrm{~m}(61 \%)$ dengan kategori cukup baik.
\end{abstract}

Pendidikan ialah suatu proses pembelajaran yang berinteraksi secara manusiawi antara siswa dengan seorang guru. Pembelajaran merupakan sesuatu aktivitas memberikan atau mengatur lingkungan sebaik-baiknya dan menggabungkan dengan pesertadidik sehingga terjadilah sebuah proses. Menurut (Asmara, 2015) pembelajaran yang baik membutuhkan proses perencanaan yang baik dan proses pelaksanaannya harus juga melibatkan banyak orang, seperti guru dan siswa, kemudian memiliki keterkaitan antara kegiatan yang satu dengan yang lain, untuk mencapai kompetensi bidang studi yang akhirnya dapat mendukung capaian kompetensi lulusan. Menurut (Rusman, 2014) tugas dari seorang guru sangatlah berat karena untuk masa depan bangsa. Pendidikan jasmani olahraga kesehatan adalah alat untuk mencapai tujuan dari pendidikan secara utuh dan pendidikan kurang lengkap tanpa adanya pendidikan jasmani olahraga dan kesehatan. Menurut (Rocha \& Clemente, 2012) di pembelajaran PJOK guru sebagai acuan untuk ditiru dan sebaagai penentu dari sebuah keputusan. Begitupun yang disampaikan (Di Brezzo, Page Glave, Gray, \& Lirgg, 2012) pembelajaran olahraga sangat penting guna dalam kurikulum dan menjadi aspek yang sangat penting dalam sekolah. Hal ini senada dengan (Roesdiyanto, 2017) beberapa pandangan memberikan tekanan bahwa pendidikan olahraga tidak dapat terpisahkan dari pendidikan sehingga PJOK tidak terpisahkan dari tujuan pendidikan yang ada di Negara ini.

Pendidikan jasmani, olahraga, dan kesehatan adalah salah satu pembelajaran yang diberikan di sekolah menengah pertama sebagai pelengkap dari proses pembelajaran yang ada. Dengan menggunakan pembelajaran PJOK peserta didik diharapkan memiliki proses belajar dan dapat mengalami perubahan perilaku. (Suherman, 2007) menyatakan pembelajaran PJOK digambarkan dengan aktivitas jasmani sehingga dapat menambahkan kebugaran, menambah keterampilan gerak, ilmu pengetahuan dan hidup sehat. Begitupun yang dinyatakan oleh (Bailey et al., 2009) Physical education and school sport mempunyai gelaran untuk dijadikan sebuah pemberi masukan terhadap tumbuh kembang kognitif dan afektif seseorang. Begitupun yang diungkapkan oleh (Hinkley et al., 2014) bahwa aktivitas fisik pada pendidikan jasmani mempunyai kekayaan terhadap kesehatan. (Fairclough, Stratton, \& Baldwin, 2002) aktivitas fisik yang dipelajari di sekolah memiliki tujuan menyediakan banyak peluang di kemudian hari yang mengarah pada manfaat fisik, psikologis, dan sosial serta berdampak pada kesehatan dan tetap aktif secara fisik. (Bailey, 2016) mengungkapkan pendidikan olahraga di sekolah adalah pemberi sosial untuk dapat dikembangkan dengan sebuah kemampuan fisik dan penyedia aktivitas gerak pada siswa. Begitupula pendapat (Trudeau \& Shephard, 2008) bahwa pendidikan jasmani mempunyai misi pendidikan dan memaksimalkan efek yang baik, 
seperti prestasi akademik dan kepatuhan dalam jangka panjang terhadap kebiasaan berolahraga. Sependapat dengan (Sallis et al., 2012) bahwa pendidikan jasmani dapat memberikan kegiatan yang lebih baik dengan peningkatan sekitar $97 \%$.

Secara umum, pembelajaran sering dikaitkan dengan pendidikan, didalam ruang lingkup pendidikan istilah pembelajaran dikaitkan dengan sebagian bentuk kegiatan yang tercakup didalam sistem pendidikan. (Dwiyogo, 2016) bahwa pembelajaran adalah sesuatu hal yang memberikan perhatian kepada siswa untuk membetulkan proses pembelajaran. Menurut (Pereira, Araújo, Farias, Bessa, \& Mesquita, 2016) pembelajaran adalah sebuah proses peningkatan dengan tugas yang diatur untuk memberikan kerja yang baik, sebagai pemecah problem dan interaksi sebuah pertemuan. Begitupula yang diungkapkan oleh (Chen, Zhu, Androzzi, \& Nam, 2016) pembelajaran terjadi ketika seseorang berpikir, beriman, percaya, dan memproses informasi dengan memperluas atau mengubah basis pengetahuan diri sendiri. Pelaksanaan pembelajaran adalah suatu hal yang dilakukan oleh guru yang mengacu dari rencana pembelajaran. Menurut (Sudjana, 2010) bahwa pelaksanaan pembelajaran sebagai suatu pemberi yang diatur seringkas mungkin dengan langkah-langkah tertentu agar pelaksanaan pembelajaran tercapai yang diinginkan. Begitupula yang disampaikan oleh (Djamarah \& Zain, 2010) yaitu pelaksanaan pembelajaran merupakan kegiatan yang memiliki nilai edukatif yang memberikan warna terhadap interaksi yang terjadi antara pendidik dan peserta didik. Dari beberapa para ahli di atas dapat disimpullkan interaksi tersebut bernilai edukatif karena pelaksanaan pembelajaran yang dilakukan diarahkan untuk mencapai tujuan pembelajaran yang telah dirumuskan sebelum pelaksanaan pembelajaran dilaksanakan.

Kegiatan pendahuluan adalah kegiatan awal dari sebuah pembelajaran yang bertujuan untuk meningkatkan motivasi dan memfokuskan perhatian peserta didik untuk ikut aktif dalam pembelajaran. Kegiatan inti ialah suatu kegiatan dimana isi didalamnya menyangkut dari materi yang diajarkan dengan siswa mengamati, menanya, menjawab, mengeksplorasi, dan mencoba. (Rusman, 2014) kegiatan inti dengan metode yang diharapkan dengan karakteristik peserta didik dan mata pelajaran, meliputi eksplorasi, elaborasi, dan konfirmasi. Kegiatan penutup adalah kegiatan penenangan atau mengondisikan tubuh kembali kesemula, dalam kegiatan penutup ini seorang guru bersama peserta didik mengulas kegiatan yang sudah dilakukan atau refleksi.

Pendidikan Jasmani, Olahraga, dan Kesehatan dapat memberikan peningkatan terhadap pergerakan dasar dan menambah sikap jujur dan tekun (Nurrochmah, 2016). Inti dari evaluasi yakni sebagai tahapan yang sangat penting dilaksanakan untuk mengetahui gambaran, apakah pembelajaran sudah dilakukan seefektif mungkin serta telah mencapai tujuan pembelajaran yang dinginkan. Di dalam proses belajar evaluasi mempunyai acuan terhadap pencapaian tujuan dan sasaran pendidikan secara umum, begitu juga terhadap PJOK (Winarno, 2014). Begitupun yang diungkapkan oleh (Spiel, 2015) tujuan evaluasi sebagai pemberi informasi tentang efektivitas program sehingga dapat memaksimalkan hasil, kualitas, dan efisiensi.

\section{METODE}

Pokok bahasan dalam penelitian ini yaitu memberikan informasi tentang pelaksanaan pembelajaran PJOK pada SMP di kecamatan Pakis dibagi menjadi empat bahasan, yaitu tahap (1) pendahuluan, (2) inti, (3) penutup, dan (4) waktu efektivitas. Kegiatan pendahuluan, meliputi kondisi guru dan peserta didik. Kegiatan inti, meliputi pembelajaran guru secara berlangsung dan kegiatan siswa selama pembelajaran berlangsung. Kegiatan penutup, meliputi rangkaian kegiatan penutup guru dan siswa. Tahap waktu efektivitas pembelajaran. Sehingga nantinya dapat digunakan untuk menjadi landasan untuk memperbaiki permasalahan yang dimiliki oleh guru Pendidikan Jasmani, Olahraga, dan Kesehatan.

Subjek dalam penelitian ini menggunakan enam sekolah yang berada di kecamatan Pakis, dan pengambilan sampel yaitu Purposive Sampling artinya sampel yang dipilih disengaja sesuai dengan persyaratan sampel yang dibutuhkan. Berikut sampel yang digunakan (1) SMPN 1 Pakis, (2) SMPN 2 Pakis, (3) SMP NU Pakis, (4) SMP IT Asy-Syadzili, (5) SMP ALFaqih, (6) SMP AL Hasib. Analisis data dalam penelitian ini yaitu dari angket siswa, observasi kegiatan pembelajaran. Sumber data yang mulanya berbentuk kuantitatif diubah menjadi kualitatif dengan analisis deskriptif kuantitatif.

Tabel 1. Klasifikasi Nilai dalam Persentase (\%)

\begin{tabular}{cccccc}
\hline Klasifikasi & Baik sekali & Baik & Cukup Baik & Kurang Baik & Tidak Baik \\
\hline Persentase & $80-100 \%$ & $66-79 \%$ & $56-65 \%$ & $40-55 \%$ & $<39 \%$ \\
\hline
\end{tabular}

(Sumber: Arikunto, 2012)

Reduksi data yang dilakukan penelitian ini yaitu pemilihan data yang telah diperoleh dari angket, observasi pembelajaran, dan dokumentasi. Hasil dari pengumpulan tersebut merupakan data yang saling mendukung sehingga peneliti dapat memilih data mana yang dibutuhkan dalam penelitian, yaitu data yang berkaitan tentang pelaksanaan pembelajaran PJOK. Sehingga data-data yang tidak berkaitan dengan hal tersebut tidak digunakan oleh peneliti. 


\section{HASIL}

Dari hasil pelaksanaan pembelajaran Pendidikan Jasmani, Olahraga, dan Kesehatan SMP Kec. Pakis menggambarkan empat tahapan, yakni kegiatan pendahuluan, inti, penutup, dan waktu efektif. Dengan data hasil analisis deskriptif kuantitatif, hasil penelitian dengan skor persentase yang didapatkan dari hasil observasi pelaksanaan pembelajaran.

Tabel 2. Data Hasil Deskriptif Kuantitatif Pelaksanaan Pembelajaran Guru PJOK

\begin{tabular}{|c|c|c|c|c|c|c|c|c|c|c|c|}
\hline \multirow{2}{*}{ No } & \multirow{2}{*}{ Aktivitas } & \multicolumn{7}{|c|}{ Guru } & \multirow{2}{*}{ Jumlah } & \multirow{2}{*}{ Rata-rata } & \multirow{2}{*}{$\%$} \\
\hline & & 1 & 2 & 3 & 4 & 5 & 6 & 7 & & & \\
\hline 1 & Kegiatan awal & $11 \mathrm{~m}$ & $11 \mathrm{~m}$ & $9,5 \mathrm{~m}$ & $11 \mathrm{~m}$ & $9,5 \mathrm{~m}$ & $12,5 \mathrm{~m}$ & $9,83 \mathrm{~m}$ & $74,5 \mathrm{~m}$ & $10,64 \mathrm{~m}$ & $9 \%$ \\
\hline 2 & Kegiatan inti & $56,5 \mathrm{~m}$ & $48 \mathrm{~m}$ & $48 \mathrm{~m}$ & $59,5 \mathrm{~m}$ & $67 \mathrm{~m}$ & $56 \mathrm{~m}$ & $60 \mathrm{~m}$ & $394,75 \mathrm{~m}$ & $56,39 \mathrm{~m}$ & $47 \%$ \\
\hline 3 & Kegiatan penutup & $6 \mathrm{~m}$ & $7 \mathrm{~m}$ & $4 \mathrm{~m}$ & $8,5 \mathrm{~m}$ & $5,6 \mathrm{~m}$ & $6 \mathrm{~m}$ & $3 \mathrm{~m}$ & $41,42 \mathrm{~m}$ & $5,91 \mathrm{~m}$ & $5 \%$ \\
\hline 4 & Waktu efektif & $73,5 \mathrm{~m}$ & $66 \mathrm{~m}$ & $62 \mathrm{~m}$ & $79,5 \mathrm{~m}$ & $82 \mathrm{~m}$ & $75 \mathrm{~m}$ & $73 \mathrm{~m}$ & $510,67 \mathrm{~m}$ & $72,95 \mathrm{~m}$ & $61 \%$ \\
\hline
\end{tabular}

Dari tabel 2 dapat disimpulkan bahwa dari keseluruhan kegiatan pelaksanaan pembelajaran guru PJOK di Kec. Pakis. yaitu dengan dibagi beberapa kegiatan yakni (1) kegiatan awal rata-rata 10,64 menit (9\%). (2) Kegiatan inti dengan rata-rata 56,39 menit (47\%). (3) Kegiatan penutup dengan rata-rata 5,91 menit (5\%). Total waktu yang digunakan oleh guru PJOK di Kec. Pakis yakni 72,95 menit (61\%) dengan kategori cukup baik.

Tabel 3. Hasil Observasi Pelaksanaan Pembelajaran di SMP N 1 Pakis

\begin{tabular}{lcccccc}
\hline \multirow{2}{*}{ Aktivitas } & \multicolumn{3}{c}{ Guru } & \multicolumn{2}{c}{ Hasil } \\
\cline { 2 - 6 } & \multicolumn{2}{c}{ A } & & B & Rerata & $\%$ \\
\hline Kegiatan Awal & $11 \mathrm{~m}$ & $9 \%$ & $11 \mathrm{~m}$ & $9 \%$ & $11 \mathrm{~m}$ & $9 \%$ \\
Kegiatan Inti & $56,50 \mathrm{~m}$ & $47 \%$ & $47,75 \mathrm{~m}$ & $40 \%$ & $52,13 \mathrm{~m}$ & $43 \%$ \\
Kegiatan Penutup & $6 \mathrm{~m}$ & $5 \%$ & $7,25 \mathrm{~m}$ & $6 \%$ & $6,63 \mathrm{~m}$ & $6 \%$ \\
Waktu Efektif & $73,5 \mathrm{~m}$ & $61 \%$ & $66 \mathrm{~m}$ & $67 \%$ & $69,75 \mathrm{~m}$ & $58 \%$ \\
\hline
\end{tabular}

Dari tabel 3 dapat disimpulkan bahwa kegiatan pelaksanaan pembelajaran PJOK di SMPN 1 Pakis yaitu dengan dibagi beberapa kegiatan, yakni (1) Kegiatan awal rata-rata 11 menit (9\%). (2) Kegiatan inti dengan rata-rata 52,13 menit (43\%). (3) kegiatan penutup dengan rata-rata 6,63 menit (6\%.) Total waktu efektif yang digunakan di SMPN 1 Pakis yaitu 69,75 menit $(58 \%)$ dengan kategori cukup baik.

Tabel 4. Hasil Observasi Pelaksanaan Pembelajaran di SMPN 2 Pakis

\begin{tabular}{lccc}
\hline \multirow{2}{*}{ Aktivitas } & \multicolumn{2}{c}{ Observer } & Hasil \\
\cline { 2 - 4 } & $\mathbf{1}$ & $\mathbf{2}$ & Rata-rata \\
\hline Kegiatan Awal & $9 \mathrm{~m}(8 \%)$ & $10 \mathrm{~m}(8 \%)$ & $9,50 \mathrm{~m}(8 \%)$ \\
Kegiatan Inti & $48,67 \mathrm{~m}(41 \%)$ & $48 \mathrm{~m}(40 \%)$ & $48,33 \mathrm{~m}(40 \%)$ \\
Kegiatan Penutup & $4 \mathrm{~m}(3 \%)$ & $4,67 \mathrm{~m}(4 \%)$ & $4,33 \mathrm{~m}(4 \%)$ \\
Waktu Efektif & $62 \mathrm{~m}(52 \%)$ & $62,33 \mathrm{~m}(52 \%)$ & $62,17 \mathrm{~m}(52 \%)$ \\
\hline
\end{tabular}

Dari tabel 4 disimpulkan bahwa kegiatan pelaksanaan pembelajaran PJOK di SMPN 2 Pakis yaitu dengan dibagi beberapa kegiatan, yakni (1) kegiatan awal rata-rata 9,50 menit (8\%), (2) kegiatan inti dengan rata-rata 48,33 menit (40\%), (3) kegiatan penutup dengan rata-rata 4,33 menit (4\%). Total waktu efektif yang digunakan di SMPN 2 Pakis yaitu 62,17 menit (52\%) dengan kategori cukup baik.

Tabel 5. Hasil Observasi Pelaksanaan Pembelajaran di SMP NU

\begin{tabular}{lccc}
\hline \multirow{2}{*}{ Aktivitas } & \multicolumn{2}{c}{ Observer } & Hasil \\
\cline { 2 - 4 } & $\mathbf{1}$ & $\mathbf{2}$ & Rata-rata \\
\hline Kegiatan Awal & $11 \mathrm{~m}(9 \%)$ & $11,33 \mathrm{~m}(9 \%)$ & $11,17 \mathrm{~m}(9 \%)$ \\
Kegiatan Inti & $59,33 \mathrm{~m}(49 \%)$ & $59,67 \mathrm{~m}(50 \%)$ & $59,50 \mathrm{~m}(50 \%)$ \\
Kegiatan Penutup & $8 \mathrm{~m}(7 \%)$ & $9,33 \mathrm{~m}(8 \%)$ & $8,67 \mathrm{~m}(7 \%)$ \\
Waktu Efektif & $78,33 \mathrm{~m}(65 \%)$ & $80,33 \mathrm{~m}(67 \%)$ & $79,33 \mathrm{~m}(66 \%)$ \\
\hline
\end{tabular}

Dari hasil tabel 5 disimpulkan bahwa kegiatan pelaksanaan pembelajaran PJOK di SMP NU yaitu dengan dibagi beberapa kegiatan yakni (1) kegiatan awal rata-rata 11,17 menit (9\%). (2) kegiatan inti dengan rata-rata 59,50 menit (50\%). (3) kegiatan penutup dengan rata-rata 8,67 menit (7\%.) Total waktu efektif yang digunakan di SMPN NU yaitu 79,33 menit (66\%) dengan kategori baik. 
Tabel 6. Hasil Pelaksanaan Pembelajaran di SMP IT Asy-Syadzili

\begin{tabular}{lccc}
\hline \multirow{2}{*}{ Aktivitas } & \multicolumn{2}{c}{ Observer } & Hasil \\
\cline { 2 - 4 } & $\mathbf{1}$ & $\mathbf{2}$ & Rata-rata \\
\hline Kegiatan Awal & $9 \mathrm{~m}(8 \%)$ & $10 \mathrm{~m}(8 \%)$ & $9,50 \mathrm{~m}(8 \%)$ \\
Kegiatan Inti & $74,67 \mathrm{~m}(62 \%)$ & $58,67 \mathrm{~m}(49 \%)$ & $66,67 \mathrm{~m}(56 \%)$ \\
Kegiatan Penutup & $5,67 \mathrm{~m}(5 \%)$ & $5,33 \mathrm{~m}(4 \%)$ & $5,50 \mathrm{~m}(5 \%)$ \\
Waktu Efektif & $89,33 \mathrm{~m}(74 \%)$ & $74 \mathrm{~m}(62 \%)$ & $81,67 \mathrm{~m}(68 \%)$ \\
\hline
\end{tabular}

Dari hasil tabel 6 disimpulkan bahwa kegiatan pelaksanaan pembelajaran PJOK di SMP IT yaitu dengan dibagi beberapa kegiatan, yakni (1) kegiatan awal rata-rata 9,50 menit (8\%), (2) kegiatan inti dengan rata-rata 66,67 menit (56\%), dan (3) kegiatan penutup dengan rata-rata 5,50 menit (5\%.) Total waktu efektif yang digunakan di SMP IT Asy-Syadzili yaitu 81,67 menit $(68 \%)$ dengan kategori baik.

Tabel 7. Hasil Observasi Pelaksanaan Pembelajaran di SMP Al Faqih

\begin{tabular}{lccc}
\hline \multirow{2}{*}{ Aktivitas } & \multicolumn{2}{c}{ Observer } & Hasil \\
\cline { 2 - 4 } & $\mathbf{1}$ & $\mathbf{2}$ & Rata-rata \\
\hline Kegiatan Awal & $12,67 \mathrm{~m}(11 \%)$ & $12,33 \mathrm{~m}(10 \%)$ & $12,50 \mathrm{~m}(10 \%)$ \\
Kegiatan Inti & $56,33 \mathrm{~m}(47 \%)$ & $55,67 \mathrm{~m}(46 \%)$ & $56 \mathrm{~m}(47 \%)$ \\
Kegiatan Penutup & $6 \mathrm{~m}(5 \%)$ & $6,67 \mathrm{~m}(5 \%)$ & $6,33 \mathrm{~m}(5 \%)$ \\
Waktu Efektif & $75 \mathrm{~m}(63 \%)$ & $74,67 \mathrm{~m}(62 \%)$ & $74,83 \mathrm{~m}(62 \%)$ \\
\hline
\end{tabular}

Dari hasil tabel 7 disimpulkan bahwa kegiatan pelaksanaan pembelajaran PJOK di SMP AL Faqih yaitu dibagi beberapa kegiatan, yakni (1) kegiatan awal rata-rata 12,50 menit (10\%), (2) kegiatan inti dengan rata-rata 56 menit (47\%), dan (3) kegiatan penutup dengan rata-rata 6,33 menit (5\%.) Total waktu efektif yang digunakan di SMPN AL-Faqih yaitu 74,83 menit $(62 \%)$ dengan kategori cukup baik.

Tabel 8. Hasil Observasi Pelaksanaan Pembelajaran di SMP Al Hasib

\begin{tabular}{lccc}
\hline \multirow{2}{*}{ Aktivitas } & \multicolumn{2}{c}{ Observer } & Hasil \\
\cline { 2 - 4 } & $\mathbf{1}$ & $\mathbf{2}$ & Rata-rata \\
\hline Kegiatan Awal & $10 \mathrm{~m}(8 \%)$ & $9,67 \mathrm{~m}(8 \%)$ & $9,83 \mathrm{~m}(8 \%)$ \\
Kegiatan Inti & $60 \mathrm{~m}(50 \%)$ & $60 \mathrm{~m}(50 \%)$ & $60 \mathrm{~m}(50 \%)$ \\
Kegiatan Penutup & $3 \mathrm{~m}(4 \%)$ & $3,67 \mathrm{~m}(4 \%)$ & $3,3(3 \%)$ \\
Waktu Efektif & $73 \mathrm{~m}(61 \%)$ & $73,33 \mathrm{~m}(61 \%)$ & $73,17 \mathrm{~m}(61 \%)$ \\
\hline
\end{tabular}

Dari hasil tabel 8 dapat disimpulkan bahwa kegiatan pelaksanaan pembelajaran PJOK di SMP AL Hasib dibagi beberapa kegiatan, yakni (1) kegiatan awal rata-rata 9,83 menit (8\%), (2) kegiatan inti dengan rata-rata 60 menit (50\%), dan (3) kegiatan penutup dengan rata-rata 3,33 menit (3\%.) Total waktu efektif yang digunakan di SMP AL Hasib yaitu 73,17 menit $(61 \%)$ dengan kategori cukup baik.

\section{PEMBAHASAN}

Pendidikan olahraga ialah suatu proses pendidikan yang menggunakan aktivitas fisik yang mana tujuannya untuk menggunakan semua fungsi tubuh untuk bergerak secara menyeluruh, untuk mencapai tujuan Pendidikan Jasmani dari segi aspek sikap, pengetahuan, dan keterampilan. Menurut (Roesdiyanto, 2017) pembelajaran pendidikan jasmani diharapkan bisa memberikan tambahan terhadap peserta didik agar menjadi manusia yang bugar secara jasmani. Kegiatan pendahuluan di SMP Kec. Pakis. berdasarkan kesimpulan dari hasil penelitian bahwa kegiatan awal rata-rata 10,64 menit (9\%) hal ini sangatlah jauh dari standart yang ada, temuan yang dilakukan oleh (Pambudi, Winarno, \& Dwiyogo, 2019) kegiatan pendahuluan dengan waktu 9 menit dan persentase 43\% yang berarti kurang baik. Begitupula hasil dari (Kurniawan, Winarno, \& Dwiyogo, 2018) bahwa guru tidak menyalurkan pendahuluan atau penguatan materi awal dan tidak memberi penjelasan tujuan sebelum pembelajaran dimulai.

Temuan di dalam lapangan mengungkapkan bahwa kegiatan pendahuluan tidak terlaksana semua, hal ini dikarenakan waktu terbuang oleh siswa yang melakukan ganti baju dan terbuang oleh jarak antara sekolah dan lapangan, hal ini tidak sesuai dengan standart permendiknas. Pendahuluan salah satunya seorang pendidik segera menyiapkan peserta didik secara psikis dan fisik guna untuk memperoleh pembelajaran serta menjelaskan tujuan pembelajaran. Dari persiapan tersebut dilaksanakan guna untuk membuat peserta didik dapat lebih siap dalam menerima pembelajaran.

Kegiatan inti di SMP Kec. Pakis. berdasarkan hasil dari penelitian bahwa kegiatan inti rata-rata 56,39 menit (47\%). Hal tersebut sangat tidak selaras dengan peraturan yang ada. Temuan di dalam lapangan mengungkapkan bahwa kegiatan inti tidak relevan dengan yang direncanakan. Hal ini dikarenakan waktu kegiatan inti terbuang oleh siswa yang sedang bermain sendiri akibatnya guru harus menenangkan siswa yang sedang bermain sendiri dan tidak memperhatikan perintah dari guru. 
Sementara itu, (Pambudi et al., 2019) waktu kegiatan inti dengan 44 menit dengan persentase $44 \%$ yang berarti kurang baik. Temuan yang dilakukan oleh (Husain, Hasan, Wahab, \& Jantan, 2015) menunjukkan bahwa 18,2\% siswa sangat menikmati kelas pendidikan jasmani olahraga kesehatan. 46,5\% menyatakan bahwa mereka menikmati kelas pendidikan jasmani olahraga kesehatan. Sementara itu, 19,2\% menyatakan bahwa kelas Pendidikan Jasmani, Olaharaga, dan Kesehatan terkadang bosan dan 16,2\% menyatakan bahwa kelas Pendidikan Jasmani, Olahraga, dan Kesehatan melelahkan dan bosan. Hal ini jelas tidak sesuai dengan peraturan yang ada di dinas pendidikan. Dari temuan tersebut dan dibandingkan dengan temuan yang telah ada dapat disimpulkan bahwa pelaksanaan pembelajaran dalam kegiatan inti masih jauh dari standard yang telah ditentukan, hal ini dapat menyebabkan kurangnya minat peserta didik dalam kegiatan inti.

Didalam kegiatan penutup di SMP Kec. Pakis. berdasarkan dari data temuan dilapangan bahwa kegiatan penutup ratarata 5,91 menit (5\%), hal tersebut tidak akurat dengan yang dikeluarkan pemerintah. (Widiyatmoko \& Maftukin, 2017) mengungkapkan bahwa seorang guru masih mebiarkan begitu saja tanpa diberikan pendinginan atas pembelajaran yang baru saja dilakukan. Sedangkan temuan dari (Pambudi et al., 2019) bahwa kegiatan penutup adalah 5 menit dengan persentase 32\% yang berarti tidak baik. Hal senada diungkapkan oleh (Kurniawan et al., 2018) bahwa sebagian guru tidak memberikan refleksi, rangkuman atau evaluasi kepada pesertadidik yang menyebaban guru tidak mengerti apakah pembelajaran yang telah dilakukan dan diterima oleh pesertadidik sudah baik atau tidak. Temuan dilapangan membuktikan bahwa dikegiatan penutup guru jarang melakukan evaluasi pembelajaran dan guru jarang melakukan pendinginan, hal tersebut dibuktikan waktu kegiatan penutup digunakan siswa untuk mandi dan ganti seragam.

Hasil penelitian pelaksanaan pembelajaran PJOK di SMP Kec. Pakis berdasarkan hasil dari keseluruhan observasi pada pelaksanaan pembelajarannya guru olahraga di lembaga dapat dijabarkan dengan (1) waktu efektif yang digunakan dalam pembelajaran adalah 72,95 menit (61\%) yang berarti cukup baik. (2) kegiatan pendahuluan dengan waktu 10,64 menit (9\%). (3) untuk kegiatan inti adalah 56,39 menit dengan persentase (47\%). (4) untuk kegiatan penutup adalah 5,91 menit (5\%). Didalam hal tersebut pelaksanaan pembelajaran Pendidikan Jasmani, Olahraga, dan Kesehatan di SMP Kec Pakis sangat jauh dari standar yang ada. Dalam alokasi waktu jam tatap muka pembelajaran SMP/MTs adalah 40 menit. Waktu pembelajaran tiap pertemuan 3x40 menit adalah 120 menit maka dari itu permasalahan ini menjadi suatu bagian terpenting yang harus dibenahi utamanya dalam hal waktu pembelajaran efektif yang lebih ditingkatkan lagi dalam pelaksanaan pembelajaran

Hasil dari observasi pelaksanaan pembelajaran pendidikan jasmani, olahraga, dan kesehatan hal ini ada terbuangnya waktu untuk mengganti pakaian olahraga, pengambilan peralatan olahraga, perjalanan menuju lapangan, hal tersebut yang cukup menyita waktu banyak dalam pembelajaran, hal seperti inilah yang menyebabkan pelaksanaan pembelajaran menjadi berkurangnya waktu efektif pembelajaran. Selain itu, hasil dari observasi pada saat kegiatan pendahuluan, guru tidak menggunakan waktu yang maksimal, seperti berdoa, presensi, dan pemanasan. Pada saat kegiatan inti, rata-rata guru menerapkan pembelajaran saintifik, seperti (1) mengamati, (2) mencoba, (3) mengasosiasi, dan (4) umpan balik. Pada kegiatan penutup, guru hanya melakukan evaluasi proses pembelajaran saja dan tidak melaksanakan kegiatan pendinginan. Hal ini sangat tidak sesuai dengan standart yang telah ditetapkan oleh peraturan mentri pendidikan. (Rachman, 2011) mengungkapkan bahwa dilaksanakannya pembelajaran pendidikan jasmani dan olahraga di Yogyakarta dengan kategori C dengan 55,5\%. Begitupula yang diungkapkan oleh (Sultoni \& Rachman, 2015) bahwa keterlaksanaan kurikulum 2013 mata pelajaran PJOK tingkat SMP pada sekolah satu atap di Kab. Probolinggo telah terlaksana tetapi masih belum semuanya dapat dijalankan sesempurna mungkin. Berbanding terbalik dibandingkan di daerah lain yang dilaksanakan oleh penelitian (Alaswati, 2016) menunjukkan bahwa pelaksanaan pembelajaran telah terlaksana dengan baik, melakukan kegiatan inti menggunakan waktu dengan baik, begitupun yang disampaikan oleh (Pujianto, Rahayu, \& Aji, 2013) dalam pelaksanaan evaluasi pembelajaran pendidikan jasmani olahraga dan kesehatan pada siswa SMP Negeri se-Kec. Karanganyar tahun pembelajaran 2012/2013 bahwa evaluasi pembelajaran telah terlaksana dengan sangat baik.

Untuk memberikan rekomendasi yang tepat atas masalah-maslah tersebut yaitu. Guru PJOK dalam melaksanakan pembelajaran haruslah melihat dan mengacu pada standart yang ada. Mulai dari kegiatan pendahuluan, kegiatan inti, kegiatan penutup, dan pelaksanaan tersebut haruslah sesuai dengan Rencana Pelaksanaan Pembelajaran (RPP) yang telah dibuat oleh guru PJOK. Durasi waktu dalam pelaksanaan haruslah diatur dan disesuaikan dengan kegiatan yang akan dilaksanakan sehingga waktu yang digunakan tepat dan maksimal. Lembaga sekolah haruslah menyediakan peralatan atau sarana yang memadai di awal semester guna untuk berjalannya pembelajaran sesuai dengan waktu yang telah ditetapkan. Begitupun yang diungkapkan oleh (Uysal, 2018) seorang guru harus menambah kegiatan efektif yang saling berkesinambungan dengan pembelajaran.

Berdasarkan hasil penelitian yang dilakukan pelakasanaan pembelajaran tidak terlaksana dengan waktu yang ada. Banyak kelemahan yang masih harus dibenahi dari pelaksanaan pendahuluan, inti, dan akhir. Wajar jika peserta didik mempunyai perilaku dan aktivitas gerak yang rendah, kebugaran yang rendah dan pola hidup yang kurang baik. Menurut (Balan, Marinescu, Ticala, \& Shaao, 2012) menyatakan bahwa Pendidikan Jasmani menentukan pengaruh besar pada kepribadian manusia keterlibatan aktivitas motoric yang menyiratkan cara berpikir dan perilaku dengan kepribadian mereka. Menurut (Di Brezzo et al., 2012) aktivitas fisik bertujuan untuk program peningkatan kesadaran akan perilaku kesehatan yang positif terhadap kebugaran jasmani. Menurut (Saichudin, 2014) gerakan yang bervariasi pada anak usia pertumbuhan akan terpengaruh pada kualitas gerak. Begitupula yang disampaikan oleh (Roesdiyanto, 2017) berkaitan dengan pengajaran berjenjang, makna dari pembelajaran di SD bertujuan pada pembentukan fisik, dan di tingkat SMP menekankan pada pengembangan dan pada jenjang SMA lebih pada penguatan materi atau pemantapan hasil belajar. 
Guru Pendidikan Jasmani Olahraga seharusnya melaksanakan tugas mengajar sesuai dengan jam mengajar setiap minggunya dan mengacu pada peraturan mentri pendidikan agar kegiatan pembelajaran dapat semaksimal mungkin dilaksanakan, hal ini dapat mengacu pada keprofesionalan dan karir seorang guru Pendidikan Jasmani Olahraga yang mana jika seorang guru PJOK dapat menjalankan sesuai dengan jam mengajarnya maka akan terbentuklah generasi penerus bangsa melalui Pendidikan Jasmani Olahraga di sekolah.

\section{SIMPULAN}

Kesimpulan dari observasi pelaksanaan pembelajaran olahraga di Kec. Pakis terdapat kesenjangan waktu antara pelaksanaan pembelajaran dengan rencana pembelajarana, kondisi dilapangan tidak sesuai dengan standar yang berlaku misal dalam kegiatan pendahuluan, inti dan penutup. Rincian dalam setiap kegiatan akan dijabarkan sebagai berikut. Kondisi kegiatan pendahuluan pembelajaran PJOK di SMP Kec. Pakis semua guru masih belum menggunakan waktu pendahuluan semaksimal mungkin, kegiatan pendahuluan berkaitan dengan presensi, berdoa, pemanasan dan pemberian pengantar pembelajaran dengan waktu kegiatan awal rata-rata 10.64 menit dengan persentase $9 \%$.

Kondisi kegiatan inti pembelajaran PJOK di SMP Kec. Pakis beberapa guru belum menggunakan waktu yang sesuai dan efektif, dengan waktu kegiatan inti rata-rata 56,39 menit dengan persentase 47\%, dalam hal ini kegiatan inti masih belum sesuai dengan yang telah disediakan dalam rencana pelaksanaan pembelajaran (RPP). Manajemen waktu dalam setiap tahapan kegiatan inti pembelajaran juga belum diatur sebagaimana mestinya, misal dalam mengamati, menanya, mencoba, mengasosiasi, dan mengomunikasikan.

Kondisi kegiatan penutup pembelajaran PJOK di SMP Kec. Pakis rata-rata guru tidak menggunakan kegiatan penutup sesuai dengan yang telah direncakan, waktu yang digunakan kegiatan penutup rata-rata 5,91 menit dengan persentase 5\%, hal ini dalam kegiatan penutup misal evaluasi pembelajran, pendinginan dan berdoa. guru hanya mebiarkan siswa bubar begitu saja jika pembelajaran telah selesai, hal ini dikarenakan siswa harus mandi dan mengganti baju untuk mengikuti kegiatan pembelajaran berikutnya, jadi kegiatan penutup sangatlah tidak sesuai. Dari hasil keseluruhan waktu efektif pembelajaran PJOK SMP Kec. Pakis rata-rata guru masih belum menggunakan waktu yang sesuai dan diperoleh waktu rata-rata 72,95 menit dengan persentase $61 \%$. Hal ini tidak sesuai yang ditetapkan oleh pemerintah dengan 3 jam mata pelajaran dengan waktu 120 menit.

\section{DAFTAR RUJUKAN}

Alaswati, S. (2016). Evaluasi Pelaksanaan Pembelajaran Kurikulum 2013 PJOK. Journal of Physical Education and Sports, 4(2), 122-128. https://doi.org/10.15640/jpesm

Arikunto, S. (2012). Dasar-Dasar Evaluasi Pendidikan: Edisi 2. Jakarta: Bumi Aksara.

Asmara, H. (2015). Profesi Kependidikan. Bandung: Alfabeta.

Bailey, R. (2016). Physical Education and Sport in Schools : A Review of Benefits and Outcomes General Article Physical Education and Sport in Schools : A Review of Benefits and Outcomes. Journal of School Health, 76(April), $397-401$. https://doi.org/10.1111/j.1746-1561.2006.00132.x

Bailey, R., Armour, K., Kirk, D., Jess, M., Pickup, I., \& Sandford, R. (2009). The Educational Benefits Claimed for Physical Education and School Sport: An Academic Review. Research Papers in Education, 24(1), 1-27. https://doi.org/10.1080/02671520701809817

Balan, V., Marinescu, G., Ticala, L., \& Shaao, M. (2012). Physical Education-Longlife Learning Factor. Procedia - Social and Behavioral Sciences, 46, 1328-1332. https://doi.org/10.1016/j.sbspro.2012.05.296

Chen, S., Zhu, X., Androzzi, J., \& Nam, Y. H. (2016). Evaluation of a Concept-Based Physical Education Unit for Energy Balance Education. Journal of Sport and Health Science, 7(3), 353-362. https://doi.org/10.1016/j.jshs.2016.06.011

Di Brezzo, R., Page Glave, A., Gray, M., \& Lirgg, C. D. (2012). Comparison of a PE4LIFE Curriculum to a Traditional Physical Education Curriculum. Journal of Physical Education and Sport, 12(3), 245-252. https://doi.org/10.7752/jpes.2012.03038

Djamarah, S. B., \& Zain, A. (2010). Strategi Belajar Mengajar. Jakarta: Rineka Cipta.

Fairclough, S., Stratton, G., \& Baldwin, G. (2002). The Contribution of Secondary School Physical Education to Lifetime Physical Activity. European Physical Education Review, 8(1), 69-84. https://doi.org/10.1177/1356336X020081005

Hinkley, T., Teychenne, M., Downing, K. L., Ball, K., Salmon, J., \& Hesketh, K. D. (2014). Early Childhood Physical Activity, Sedentary Behaviors and Psychosocial Well-Being: A Systematic Review. Preventive Medicine, 62, $182-192$. https://doi.org/10.1016/j.ypmed.2014.02.007

Husain, M. Z., Hasan, A., Wahab, N. B. A., \& Jantan, J. (2015). Determining Teaching Effectiveness for Physical Education Teacher. Procedia - Social and Behavioral Sciences, 172, 733-740. https://doi.org/10.1016/j.sbspro.2015.01.426

Kurniawan, R., Winarno, M. E., \& Dwiyogo, W. D. (2018). Evaluasi Pembelajaran Pendidikan Jasmani, Olahraga, dan Kesehatan pada Siswa SMA Menggunakan Model Countenance. Jurnal Pendidikan: Teori, Penelitian, dan Pengembangan, 3(10), 1253-1264.

Nurrochmah, S. (2016). Tes dan Pengukuran dalam Pendidikan Jasmani dan Keolahragaan.

Pambudi, M. I., Winarno, M. E., \& Dwiyogo, W. D. (2019). Perencanaan dan Pelaksanaan Pembelajaran Pendidikan Jasmani Olahraga Kesehatan. Jurnal Pendidikan: Teori, Penelitian, dan Pengembangan, 4(1), 110-116. 
Pereira, J., Araújo, R., Farias, C., Bessa, C., \& Mesquita, I. (2016). Sport Education and Direct Instruction Units: Comparison of Student Knowledge Development in Athletics. Journal of Sports Science and Medicine, 15(4), 569-577.

Aji, D. S., Rahayu, t., \& Pujianto, A. (2013). Survei Proses Pelaksanaan Evaluasi Pembelajaran Penjas Olahraga dan Kesehatan oleh Guru di SMP Negeri Se-Kecamatan Karanganyar Kabupaten Kebumen. Journal of Physical Education, Sport, Health and Recreation, 2(6), 380-382.

Rachman, H. A. (2011). Keterlaksanaan Pendidikan Jasmani dan Olahraga di Daerah Istimewa Yogyakarta. Jurnal Pendidikan Jasmani Indonesia, 8(1), 38-47.

Rocha, R. F., \& Clemente, F. M. (2012). Expertise in Sport and Physical Education: Review through Essential Factors. Journal of Physical Education and Sport, 12(4), 557-559. https://doi.org/10.7752/jpes.2012.04082

Roesdiyanto. (2017). Kompetensi Profesional Guru Pendidikan Jasmani, Olahraga, dan Kesehatan (Dalam Kompetensi Inti Pemahaman Tujuan Pembelajaran dan Memilih Materi Pembelajaran Sesuai dengan Tingkat Perkembangan Peserta Didik. 1(1), 624-630.

Rusman. (2014). Model-Model Pembelajaran Mengembangkan Profesionalisme Guru. Jakarta: RajaWali Pers.

Saichudin. (2014). Stres Oksidatif Pemicu Utama Kematian Sel Purkinje Otak Kecil (Cerebellum). Jurnal Sport Science, 4(1), $5-11$.

Sallis, J. F., McKenzie, T. L., Beets, M. W., Beighle, A., Erwin, H., \& Lee, S. (2012). Physical Education's Role in Public Health: Steps Forward and Backward Over 20 Years and Hope for the Future. Research Quarterly for Exercise and Sport, 83(2), 125-135. https://doi.org/10.1080/02701367.2012.10599842

Sudjana, N. (2010). Penilaian Hasil Proses Belajar Mengajar (Cet. XV). Bandung: PT. Ramaja Rosdakarya.

Suherman, W. (2007). Pendidikan Jasmani sebagai Pembentuk Fondasi yang Kokoh bagi Tumbuh Kembang Anak. Pidato Pengukuhan Guru Besar. Retrieved from http://staff.uny.ac.id/sites/default/files/131808337/WSSuhermanPidatoKukuh_0.pdf

Sultoni, M. A., \& Rachman, A. (2015). Keterlaksanaan Kurikulum 2013 Mata Pelajaran Pjok Tingkat SMP pada Sekolah Satu Atap di Pulau Gili Ketapang dan Wilayah Kabupaten Probolinggo. Jurnal Pendidikan Olahraga dan Kesehatan, 3(1), 243-248.

Trudeau, F., \& Shephard, R. J. (2008). Phoohysical Education, School Physical Activity, School Sports, and Academic Performance. International Journal of Behavioral Nutrition and Physical Activity, 5(1), 10. https://doi.org/10.1186/1479-

Uysal, D. (2018). European Journal of Foreign Language Teaching Negative Feelings of Turkish Students. 120-140. https://doi.org/10.5281/zenodo.1469726

Widiyatmoko, F.A., \& Hudah, M. (2017). Evaluasi Implementasi Pendidikan Nilai Dalam Pembelajaran Penjas. Jurnal Ilmiah Penjas, 3(2), 44-60.

Winarno, M. E. (2014). Evaluasi Hasil Pendidikan Jasmani Olahraga dan Kesehatan. Malang: Universitas Negeri Malang. 